\title{
Effect of Heating Rate on the Phases Formation in Ti-20 wt. \% Al Powder Mixture
}

Andrea Školáková, Pavel Salvetr, Pavel Novák

University of Chemistry and Technology in Prague, Department of Metals and Corrosion Engineering, Technická 5, 166 28 Prague 6, Czech Republic, E-mail: skolakoa@vscht.cz, salvetrp@vscht.cz, panovak@vscht.cz

In this work, the effect of heating rate on the reaction temperatures in Ti-20 wt. \% Al powder mixture subjected to reactive sintering process were studied and microstructure, phase composition and porosity of the reaction products were described. This system was studied because the alloys based on Ti-Al intermetallics are modern high-temperature materials and their production by common metallurgical routes is problematic. Reactive sintering could potentially replace currently used method - melt metallurgy. However, many phases form during this process and some of them are undesired. For this reason, it is necessary to describe the temperatures and other reaction conditions of their formation. One of these parameters is a heating rate. The heating rate affects reaction temperatures, phase composition as well as porosity significantly. Therefore, various heating rates were tested and the reaction temperatures were determined. The heating was recorded by optical pyrometer and one exothermic reaction was observed. It was found that this reaction is associated mainly with the formation of $\mathrm{Ti}_{3} \mathrm{Al}$ phase. Further, it was revealed that porosity decreased with increasing heating rate. This work offers data important for thermodynamic calculation and description of intermetallic phases formation during reactive sintering process.

Keywords: thermal analysis, reactive sintering, microstructure, phase composition

\section{Introduction}

Ti-Al alloys belong to the group of materials with the potential to replace nickel and iron-based superalloys [1, 2]. For this reason, they have been extensively studied especially in temperature range of $500-900{ }^{\circ} \mathrm{C}$ in which they should be mainly used [3]. Turbine blades for aircraft engines and stationary turbines or space vehicles could be made of these alloys $[1,4,5]$. They provide low density, superior elevated temperature strength, excellent creep characteristics and corrosion resistance [1, 6, 7]. Despite of these all advantages, titanium aluminides have been not applied widely. Their major problem lies in lack of ductility at room temperature associated with poor workability and castability $[8,9,10]$.

Many methods have been utilized in their synthesis such as Vaccum Arc Remelting (VAR), conventional melting and casting processes [1]. However, very high melting points and resulted brittleness cause that new methods for their production have been studied. More energy is consumed to make melt and whole process is considerably expensive [9]. Research is mainly focused on powder metallurgy technique, in particular the reactive sintering $[1,2]$. Typical characteristics for this method is time and energy savings and self-sustaining propagation of energy due to highly exothermic nature of reactions [4, $9,11]$. Reactive sintering consists in the heating of mixture of elemental powders and it is the most common used method for sintering of intermetallics [12-16]. Generally in aluminides system, liquid phase forms and helps to propagate and accelerate reaction and consolidation because this liquid phase is gradually consumed [2]. For this reason, combustion of reaction is usually initiated at the temperature of melting point of aluminium in Ti-Al system [2]. Many phases, including unwanted ones, form during this process. Thus, it is necessary to describe mechanism of their formation, not only pay attention to their fabrication. Many parameters affecting their formation are needed to know and to control. These include chemical composition, heating rate, temperature and particle sizes.

Current research works provide contradictory results in this area of research and many studies have focused on system enriched by aluminium corresponding to $\mathrm{TiAl}_{3}$ phase. TiAl and $\mathrm{Ti}_{3} \mathrm{Al}$ aluminides have been studied especially for high temperature applications [2]. However, many phases form during sintering all of these intermetallics. It is believed that intermetallics formation is controlled by diffusion of aluminium through $\mathrm{TiAl}_{3}$ in $\mathrm{Ti}-\mathrm{Al}$ system [8] meanwhile work [17] found that diffusion of titanium through this phase is dominated. The first phase, which forms after the reaching of melting point of aluminium, is $\mathrm{TiAl}_{3}$ phase. Other phases $\mathrm{TiAl}$ and $\mathrm{Ti}_{3} \mathrm{Al}$ form with proceeding reaction [18]. For this reason, SHS reaction is initiated when temperature reaches the melting point of aluminium. Besides this fact, work [9] showed that solid-state diffusion appeared at approximately 200 $\mathrm{K}$ below melting point and combustion reaction is triggered by this state. The amount of molten phase then increases with proceeding combustion reaction. Other work [19] showed that formation of $\mathrm{TiAl}_{3}$ phase is controlled by the rate of chemical reaction at temperatures higher than melting point of aluminium. Initiation temperature [20] and heating rate [21] significantly affected resulted microstructure and phase composition. Obtained microstructure consists of only two phases - TiAl, $\mathrm{Ti}_{3} \mathrm{Al}$ [20] or of a large amount of $\mathrm{Ti}_{3} \mathrm{Al}, \mathrm{TiAl}_{3}$ and small amount of TiAl and Ti [22] depending on these two conditions in TiAl-based alloys. Start of SHS reaction as well as combustion reaction also increases with increasing heating rate. Too high heating rate is not beneficial to the precombustion reaction prior to the melting of aluminium [22]. For this reason, temperature-time profile of the combustion reaction at various heating rates should be observed to determine which phase form preferentially under given reaction condition and at which temperatures 
reactions start.

In this work, the effect of various heating rates was observed in Ti-20Al (in wt. \%) powder mixture. This chemical composition represents $\mathrm{Ti}_{3} \mathrm{Al}$ phase. Reaction temperatures, microstructure and phase composition were studied after each heating. Samples were prepared by reactive sintering with heating localized on one side of sample in induction furnace.

\section{Experimental}

Mixture of Ti-20Al (in wt. \%) was prepared from pure powders of titanium (purity $99.5 \%$, particle size $44 \mu \mathrm{m}$ ) and aluminium $(99.62 \%, 44 \mu \mathrm{m})$ and blended homogeneously. Cylindrical green bodies with the diameter of 10 $\mathrm{mm}$ and weight of $3 \mathrm{~g}$ were obtained by uniaxial compression at a pressure of $450 \mathrm{MPa}$ for five minutes using universal loading machine LabTest 5.250SP1-VM. Compressed powder mixtures were consequently inserted into induction furnace and heated at various heating rate under Ar atmosphere. Heating was recorded by optical pyrometer Optris OPTP20-2M and achieved heating rate was determined from the slope of obtained curves. This method is actually a kind of thermal analysis which enables much higher heating rates, which are impossible to reach during common differential thermal analysis. Resulting heating rates were $-25 ; 63 ; 96$ and $109^{\circ} \mathrm{C} \cdot \mathrm{min}^{-1}$.

Subsequently, samples were ground by sandpapers with SiC abrasive particles (P80 - P4000), polished by suspension Eposil $\mathrm{F}$ with hydrogen peroxide (volume 1:6) and etched by Kroll's reagent $\left(5 \mathrm{ml} \mathrm{HNO}_{3}, 10 \mathrm{ml} \mathrm{HF}, 85\right.$ $\mathrm{ml} \mathrm{H}_{2} \mathrm{O}$ ). Microstructure was observed by scanning electron microscope TESCAN VEGA 3 LMU equipped with the OXFORD Instruments X-max $20 \mathrm{~mm}^{2}$ SDD EDS analyzer for identification of the chemical composition of the individual phases. Phase composition was determined by X-ray diffraction and evaluated using PANalytical X'pert Pro software package with PDF2 database. Image analysis was carried out by the means of ImageJ software in order to determine porosity.

\section{Results}

Fig. 1 shows all curves obtained at various heating rates. All curves contained only one peak which is associated with exothermic reaction during which the intermetallic phase formed. The lowest heating rate caused that reaction started at $621{ }^{\circ} \mathrm{C}$ (Tab. 1) and took for $60 \mathrm{~s}$. This temperature is called as onset temperature and this one is labelled $\mathrm{T}_{\text {onset. }}$ The maximum of this temperature was 658 ${ }^{\circ} \mathrm{C}$ (Tab. 1) and this one is called combustion temperature and it is used for calculations of enthalpies. Temperature of the end of reaction is labelled $\mathrm{T}_{\text {offset }}$ and reached the temperature $640{ }^{\circ} \mathrm{C}$. As it can be seen, temperatures did not exceed temperature of melting point of aluminium suggesting reaction in solid-solid state at heating rate 25 ${ }^{\circ} \mathrm{C} \cdot \mathrm{min}^{-1}$. Microstructure was composed of unreacted titanium surrounded by $\mathrm{Ti}_{3} \mathrm{Al}$ phase (Fig. 2). EDS analysis showed that titanium contained approximately $3 \mathrm{wt} . \%$ of aluminium. TiAl phase was found between the regions of $\mathrm{Ti}_{3} \mathrm{Al}$ phase. It can be supposed that $\mathrm{Ti}_{3} \mathrm{Al}$ phase probably formed by the reaction between titanium and aluminium particles which was probably followed by the reaction of $\mathrm{Ti}_{3} \mathrm{Al}$ phase with titanium/aluminium and TiAl phase arised. XRD analysis confirmed these phases and also $\mathrm{Ti}_{2} \mathrm{Al}_{5}$ phase (Tab. 2).

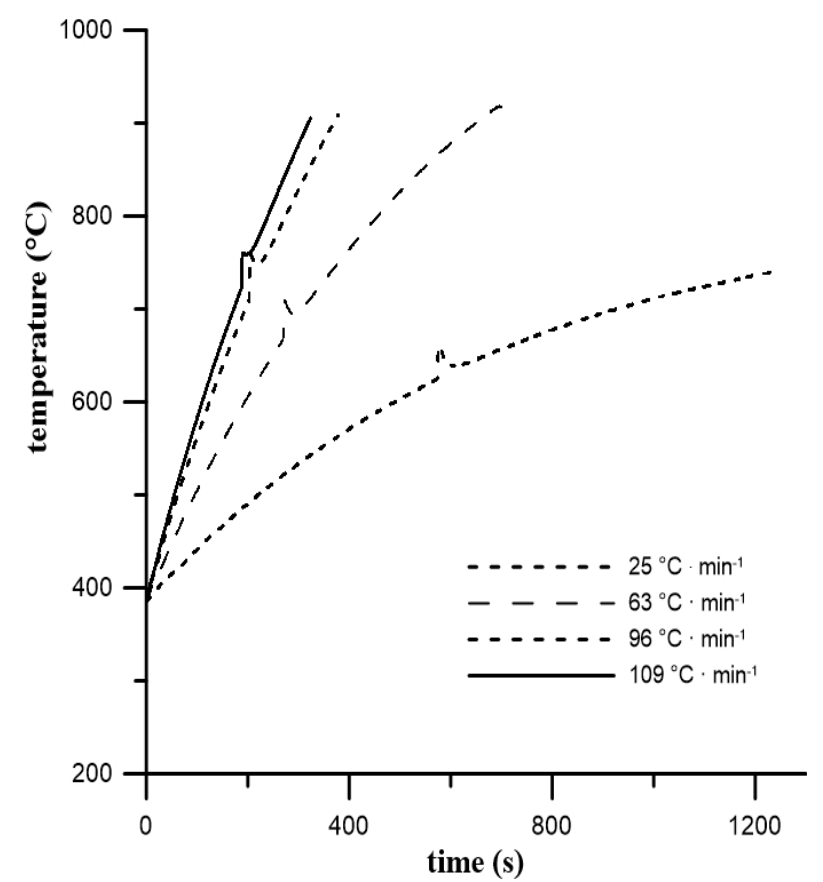

Fig. 1 Heating curves of Ti-20Al (in wt. \%) powder mixture recorded by optical pyrometer

Higher heating rate of $63{ }^{\circ} \mathrm{C} \cdot \mathrm{min}^{-1}$ caused that the reaction temperatures were moved to higher values (Tab. 1) and reaction started at approximately melting of aluminium $\left(\mathrm{T}_{\text {onset }} 659^{\circ} \mathrm{C}\right)$. Maximum of peak was $700{ }^{\circ} \mathrm{C}$ and reaction ended at $697{ }^{\circ} \mathrm{C}$. Time, during which the reaction was observed, was shorter than before. This reaction took $40 \mathrm{~s}$. So, with increasing heating rate reaction time decreases and phases formed faster. Unreacted particles of titanium were present again (Fig. 3). $\mathrm{Ti}_{3} \mathrm{Al}$ phase surrounded them and TiAl phase was always found between $\mathrm{Ti}_{3} \mathrm{Al}$ phases probably at the original places of aluminium particles. XRD analysis detected also aluminium enriched $\mathrm{Ti}_{2} \mathrm{Al}_{5}$ phase which was already found after heating at $25^{\circ} \mathrm{C} \cdot \mathrm{min}^{-1}$. In work [2] authors found that TiAl phase formed thanks to the energy released by the reaction between titanium and $\mathrm{TiAl}_{3}$ phase followed by the formation of $\mathrm{Ti}_{3} \mathrm{Al}$ and $\mathrm{TiAl}_{2}$ phase. In our case, our system is enriched by titanium and thus $\mathrm{Ti}_{3} \mathrm{Al}$ phase reacted with titanium and released energy allows to form TiAl phase. $\mathrm{Ti}_{2} \mathrm{Al}_{5}$ phase had probably formed before all of the other Ti-Al phases as an intermediate. It can be considered because work [23] showed that phase with a ratio 2:5 formed preferentially.

Tab. 1 Reaction temperatures

\begin{tabular}{|c|c|c|c|}
\hline $\begin{array}{c}\text { Heating rate } \\
\left({ }^{\circ} \mathbf{C} \cdot \mathbf{m i n}^{-\mathbf{1}}\right)\end{array}$ & $\begin{array}{c}\mathbf{T}_{\text {onset }} \\
\left({ }^{\circ} \mathbf{C}\right)\end{array}$ & $\begin{array}{c}\mathbf{T}_{\text {maximum }} \\
\left({ }^{\circ} \mathbf{C}\right)\end{array}$ & $\begin{array}{c}\mathbf{T}_{\text {offset }} \\
\left({ }^{\circ} \mathbf{C}\right)\end{array}$ \\
\hline 25 & 621 & 658 & 640 \\
\hline 63 & 659 & 700 & 697 \\
\hline 96 & 706 & 751 & 748 \\
\hline 109 & 716 & 760 & 759 \\
\hline
\end{tabular}




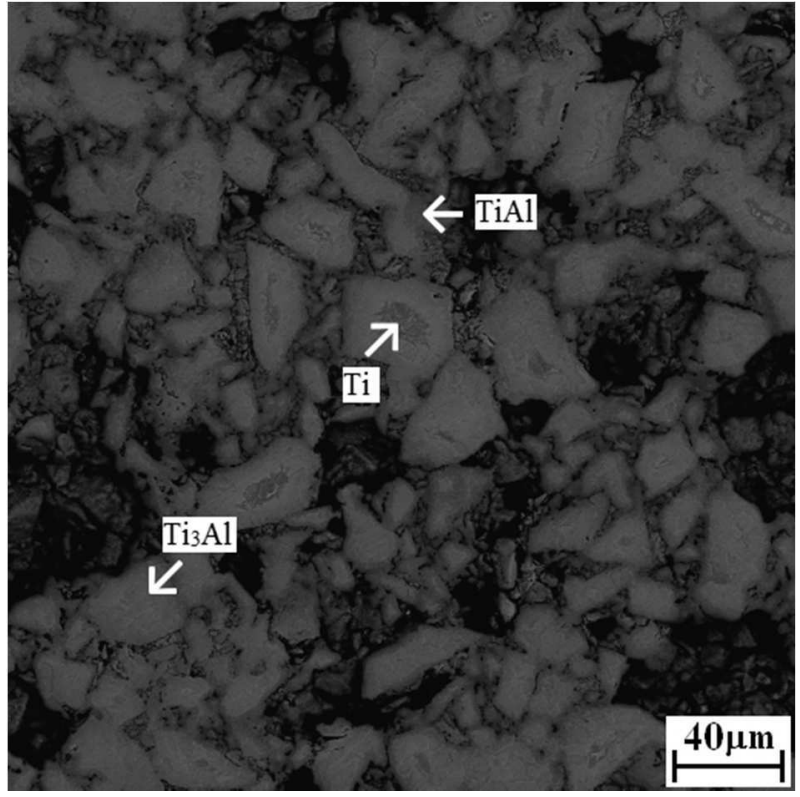

Fig. 2 Microstructure of Ti-20 wt. \% Al obtained at 25 ${ }^{\circ} \mathrm{C} \cdot \mathrm{min}^{-1}$

Tab. 2 Phase composition

\begin{tabular}{|c|c|}
\hline Heating rate $\left({ }^{\circ} \mathbf{C} \cdot \mathbf{m i n}^{-1}\right)$ & Phase composition \\
\hline 25 & $\mathrm{Ti}, \mathrm{Ti}_{3} \mathrm{Al}, \mathrm{TiAl}, \mathrm{Ti}_{2} \mathrm{Al}_{5}$ \\
\hline 63 & $\mathrm{Ti}, \mathrm{Ti}_{3} \mathrm{Al}, \mathrm{TiAl}, \mathrm{Ti}_{2} \mathrm{Al}_{5}$ \\
\hline 96 & $\mathrm{Ti}, \mathrm{Ti}_{3} \mathrm{Al}, \mathrm{TiAl}, \mathrm{Ti}_{2} \mathrm{Al}_{5}$ \\
\hline 109 & $\mathrm{Ti}, \mathrm{Ti}{ }_{3} \mathrm{Al}, \mathrm{TiAl}, \mathrm{Ti}_{2} \mathrm{Al}_{5}$ \\
\hline
\end{tabular}

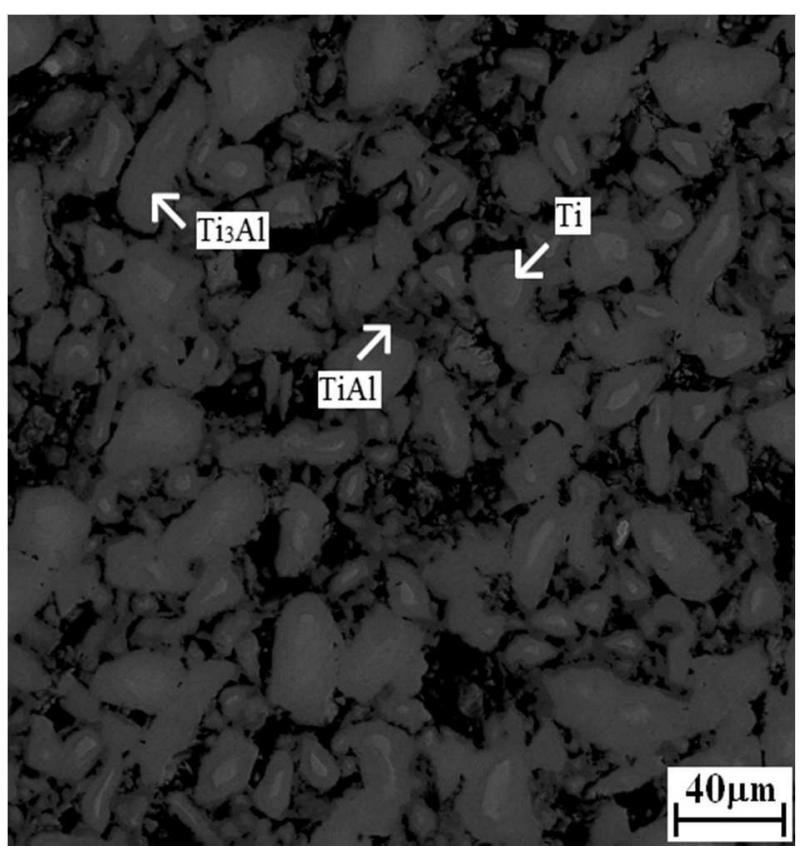

Fig. 3 Microstructure of Ti-20wt. \% Al obtained at 63 ${ }^{\circ} \mathrm{C} \cdot \mathrm{min}^{-1}$

Reaction took for $20 \mathrm{~s}$ with combustion temperature of $751^{\circ} \mathrm{C}$ (Tab. 1) after heating rate at $96^{\circ} \mathrm{C} \cdot \mathrm{min}^{-1}$. Onset $\left(706{ }^{\circ} \mathrm{C}\right)$ and offset $\left(748^{\circ} \mathrm{C}\right)$ temperatures also increased (Tab. 1). Hence, heating rate affected reaction temperatures again. On the other hand, microstructure (Fig. 4) and phase composition (Tab. 2) does not differ from the one obtained after heating at $63{ }^{\circ} \mathrm{C} \cdot \mathrm{min}^{-1}$.

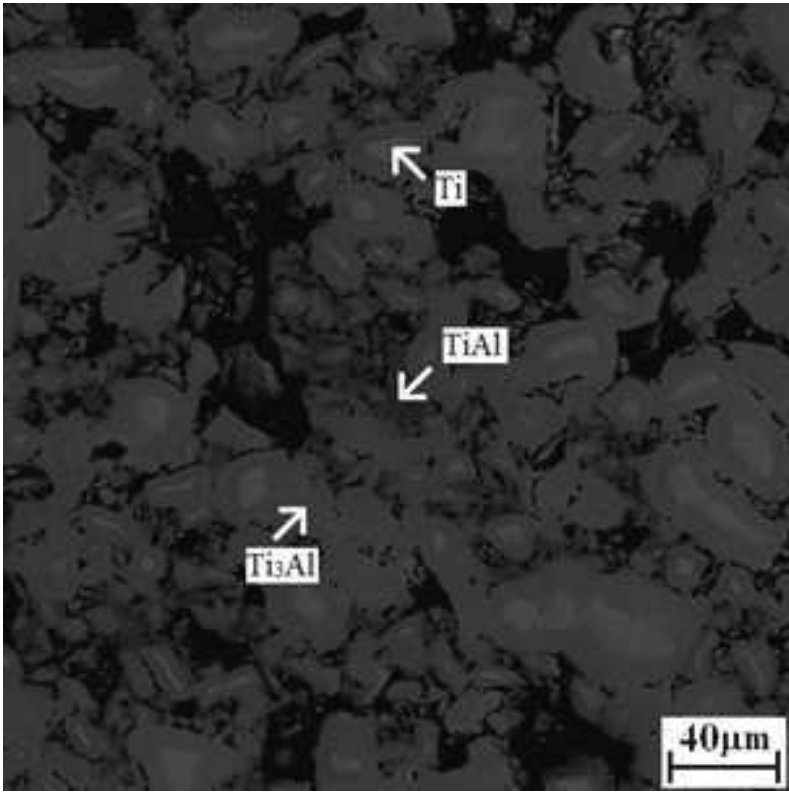

Fig. 4 Microstructure of Ti-20 wt. \% Al obtained at 96 ${ }^{\circ} \mathrm{C} \cdot \mathrm{min}^{-1}$

Same trend could be observed after heating at 109 ${ }^{\circ} \mathrm{C} \cdot \mathrm{min}^{-1}$. Reaction temperatures (Tab. 1$)$ increased $\left(\mathrm{T}_{\text {onset }}\right.$ $716{ }^{\circ} \mathrm{C}, \mathrm{T}_{\text {combustion }} 760{ }^{\circ} \mathrm{C}$ and $\mathrm{T}_{\text {offset }} 759^{\circ} \mathrm{C}$ ) and reaction time decreased to $17 \mathrm{~s}$. Microstructure did not change significantly but larger areas of TiAl phase was evident (Fig. 5).

On the base of results, it could be assumed that exothermic reaction is associated with the formation of $\mathrm{Ti}_{3} \mathrm{Al}$ phase, which formed by the reaction between solid titanium with solid aluminium (only in the case of heating rate $\left.25^{\circ} \mathrm{C} \cdot \mathrm{min}^{-1}\right)$ or by the reaction between solid titanium and liquid aluminium at heating rates higher than 63 ${ }^{\circ} \mathrm{C} \cdot \mathrm{min}^{-1}$. TiAl phase probably formed by the reaction of $\mathrm{Ti}_{2} \mathrm{Al}_{5} / \mathrm{Ti}_{3} \mathrm{Al}$ with titanium or with aluminium.

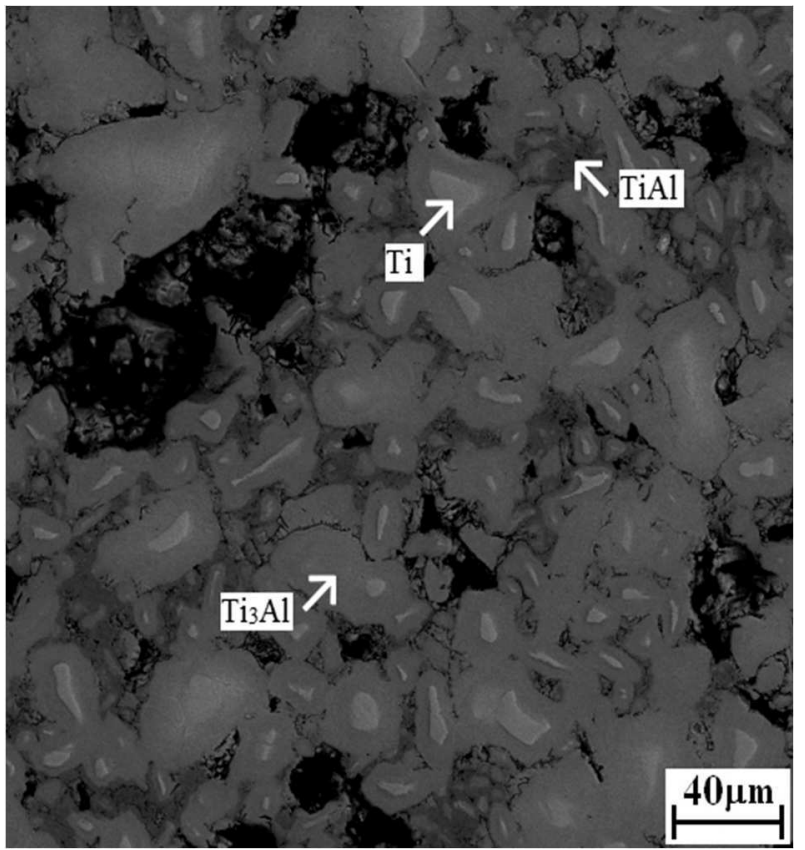

Fig. 5 Microstructure of Ti-20 wt. \% Al obtained at 109 ${ }^{\circ} \mathrm{C} \cdot \mathrm{min}^{-1}$ 
Effect of heating rate on the porosity was also observed. It was found that with increasing heating rate porosity decreased (Fig. 6). So, the increase of heating rate improved the homogeneity of obtained samples and reduced porosity. Reactions are much more exothermic and thus released heat is probably sufficient to melt the sample locally. However, it is impossible to avoid pores completely because pores formed through the Kirkendall effect which appeares during reactive sintering [11].

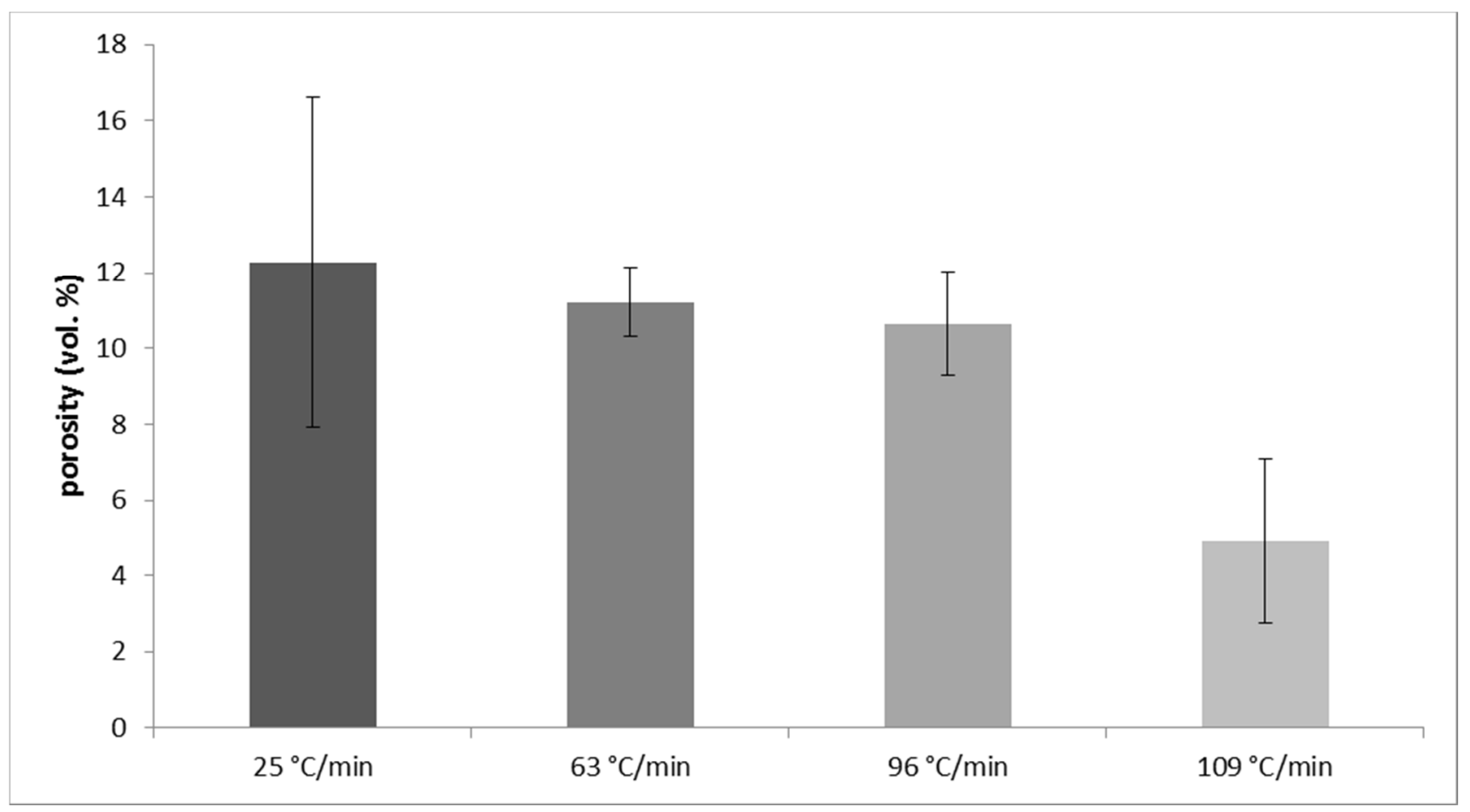

Fig. 6 Resulted porosity

\section{Conclusion}

$\mathrm{T}_{\text {onset, }} \mathrm{T}_{\text {combustion }}$ and $\mathrm{T}_{\text {offset }}$ temperatures of the reactions in TiAl20 powder mixture were determined for various heating rates. Presented results showed that reaction temperatures associated with SHS reaction increased with increasing heating rate in Ti-20Al (in wt. \%) system. Increasing heating rate accelerated the chemical reactions, which produce intermetallics. Microstructure was always composed of unreacted titanium surrounded by $\mathrm{Ti}_{3} \mathrm{Al}$ phase and $\mathrm{TiAl}$ phase. In this work, $\mathrm{Ti}_{2} \mathrm{Al}_{5}$ phase was found and it can be expected that this phase acts a reaction intermediate in this system. Further, it was confirmed that porosity which is typical for SHS sintered samples decreased with increasing heating rate in Ti-20 wt. \% Al system.

\section{Acknowledgement}

This research was financially supported by Czech Science Foundation, project P108/12/G043.

\section{References}

[1] Agote, I., COLETO, J., GUtiÉRreZ, M., SARGSYAN, A., GARCÍA DE CORTAZAR, M., LAGOS, M. A., KVANIN, V. L., BALIKHINA, N. T., VADCHENKO, S.G., BOROVINSKAYA, I. P., SYTSCHEV, A. E., PAMBAGUIAN, L. (2008). Production of $\gamma$-TiAl based alloy by combustion synthesis + compaction route, characterization and application. In: Kovove Materialy, Vol. 46, No. 2, pp. 87 - 95. Slovak Academy of Sciences. Slovak Republic.

[2] DJANARTHANY, S., VIALA, J.-C., BOUIX, J. (2001). An overview of monolithic titanium aluminides based on $\mathrm{Ti}_{3} \mathrm{Al}$ and TiAl. In: Materials Chemistry and Physics, Vol. 72, No. 3, pp. $301-$ 319. Elsevier. Netherlands.

[3] ANDREEV, D. E., SANIN, V. N., YUKHVID, V. I. (2009). Cast alloy production on the basis of titanium aluminide with centrifugal SHS method. In: Inorganic Materials, Vol. 45, No. 8, pp. $867-$ 872. Springer. Germany.

[4] LAGOS, M. A., AGOTE, I., SAN JUAN, J. M., HENNICKE, J. (2014). Fabrication of TiAl alloys by alternative powder methods. In: Gamma Titanium Aluminide Alloys 2014: A Collection of Research on Innovation and Commercialization of Gamma Alloy Technology, pp. 77 - 82. Wiley Online Library. USA.

[5] CLEMENS, H., KESTLER, H. (2000). Processing and applications of intermetallic $\gamma$-TiAl-based alloys. In. Advanced engineering materials, Vol. 2, No. 9, pp. $551-570$.

[6] WEI, N., HAN, X., ZHANG, X., CAO, Y., GUO, C., LU, Z., JIANG, F. (2016). Characterization and properties of intermetallic $\mathrm{Al}_{3} \mathrm{Ti}$ alloy synthesized by reactive sintering in vacuum. In: Journal 
of Materials Research, Vol. 31, No. 17, pp. 2706 - 2713. Cambridge Core. United Kingdom. Wiley Online Library. USA.

[7] UENISHI, K., KOBAYASHI, K. F. (1996). Processing of intermetallic compounds for structural applications at high temperature. In: intermetallics, Vol. 4, pp. S95 - S101. Elsevier. Netherlands.

[8] MIRJALILI, M., SOLTANIEH, M., MATSUURA, K., OHNO, M. (2013). On the kinetics of $\mathrm{TiAl}_{3}$ intermetallic layer formation in the titanium and aluminium diffusion couple. In: Intermetallics, Vol. 32, pp. 297 - 302. Elsevier. Netherlands.

[9] KOBASHI, M., INOGUCHI, N., KANETAKE, N. (2010). Effect of elemental powder blending ratio on combustion foaming behavior of porous Al$\mathrm{Ti}$ intermetallics and $\mathrm{Al}_{3} \mathrm{Ti} / \mathrm{Al}$ composites. In: Intermetallics, Vol. 18, pp. 1039 - 1045. Elsevier. Netherlands.

[10] YU, S., ZHIPENG, W., LIANXI, H., BINGHUA, W., TAIQING, D. (2017). Characterization on solid phase diffusion reaction behavior and diffusion reaction kinetic of Ti/Al. In: Rare Metal Materials and Engineering, Vol. 46, No. 8, pp. 2080 - 2086. Elsevier. Netherlands.

[11] JIANG, Y., HE, Y. H., HUANG, B. Y., ZOU, J., HUANG, H., XU, N. P., LIU, C. T. (2011). Criterion to control self-propagation high temperature synthesis for porous Ti-Al intermetallics. In: Powder Metallurgy, Vol. 54, No. 3, pp. $404-407$. Taylor \& Francis. United Kingdom.

[12] ŠKOLÁKOVÁ, A., NOVÁK, P., SALVETR, P. (2016). Influence of elements with high affinity to oxygen on microstructure and phase composition of Ni-Ti alloy. In: Manufacturing technology, Vol. 16, No. 4, pp. 808 - 814. UJP. Czech Republic.

[13] ŠKOLÁKOVÁ, A., NOVÁK, P., SALVETR, P. (2016). Thermal analysis of Ni-Ti-X alloys prepared by Self-propagating High-temperature Synthesis. In: Manufacturing technology, Vol. 16, No. 5, pp. 1146 - 1150. UJP. Czech Republic.

[14] SAlVETR, P., ŠKOLÁKOVÁ, A., NOVÁK, P. (2016). Changes in microstructure and properties of Ni-Ti alloy after addition of ternary alloying element. In: Manufacturing technology, Vol. 16, No. 6, pp. 1359 - 1363. UJP. Czech Republic.

[15] SALVETR, P., DANEY, B., NOVÁK, P. (2016). Comparison of Ni-Ti-Si alloy prepared by various powder metallurgy routes. In: Manufacturing technology, Vol. 16, No. 5, pp. 1136 - 1140. UJP. Czech Republic.

[16] SALVETR, P., NOVÁK, P., MORAVEC, H. (2015). Ni-Ti alloys produced by powder metallurgy. In: Manufacturing technology, Vol. 15, No. 4, pp. 689 - 694. UJP. Czech Republic.

[17] QIN, J., CHEN, G., WANG, B., HU, N., HAN, F., DU, Z. (2015). Formation of in-situ $\mathrm{Al}_{3}$ Ti particles from globular Ti powders and Al alloy melt under ultrasonic vibration. In: Journal of Alloys and Compounds, Vol. 653, pp. 32 - 38. Elsevier. Netherlands.

[18] YANG, W. Y., WEATHERLY, G. C. (1996). A study of combustion synthesis of Ti-Al intermetallic compounds. In: Journal of Material Science, Vol. 31, No. 14, pp. 3707 - 3713. Springer. Germany.

[19] ŠKOLÁKOVÁ, A., SALVETR, P., NOVÁK, P., NÝVLTOVÁ, M. (2017). Formation of phases in Ti-Al system at $800^{\circ} \mathrm{C}$. In: Manufacturing Technology, Vol. 17, No. 5, pp. 838 -842. UJP. Czech Republic.

[20] XIANG, X., BAIYUN, H. (1995). The process and mechanism of TiAl-based alloy synthesized from Ti and Al powders. In: Journal of Central South University of Technology, Vol. 2, No. 2, pp. 8 - 11. Springer. Germany.

[21] NOVÁK, P., MICHALCOVÁ, A., ŠKOLÁKOVÁ, A., PRŮŠA, F., KŘÍŽ, J., MAREK, I., KUBATÍK, T. F., KARLÍK, M., HAUŠILD, P., KOPEČEK, J. (2015). Effect of heating rate on the formation of intermetallics during SHS process. In: Acta Physica Polonica, Vol. 4, No. 128, pp. 561 - 563. Polish Academy of Sciences Institute of physics. Poland.

[22] MA, Y., FAN, Q., ZHANG, J., SHI, J., XIAO, G., GU, M. (2008). Microstructural evolution during Self-propagating High-temperature Synthesis of Ti-Al system. In: Journal of Wuhan University of Technology-Mater. Sci. Ed., Vol. 23, No. 3, pp. $381-385$. Spronger. Germany.

[23] NOVÁK, P., MICHALCOVÁ, A., MAREK, I., MUDROVÁ, M., SAKSL, K., BEDNARČÍK, J., ZIKMUND, P., VOJTĚCH, D. (2013). On the formation of intermetallics in Fe-Al system - An in situ XRD study. In: Intermetallics, Vol. 32, pp. 127 - 136. Elsevier. Netherlands. 